\title{
Pengaruh Proses Pemasakan dan Penambahan Bahan Pengawet terhadap Karakteristik Lemang Selama Masa penyimpanan
}

\author{
The Effect of Cooking Method and Preservative on Storage Time \\ of Lemang (Rice Bamboo)
}

\section{Enny Sholichah ${ }^{1}$, Rima Kumalasari', Nok Afifah ${ }^{1}$, Novita Indrianti ${ }^{1}$, Faradila Nurintan Firdaus $^{2}$, Ari Rahayuningtyas ${ }^{1}$, dan Titik Budiati ${ }^{2}$}

\author{
${ }^{1}$ Pusat Penelitian Teknologi Tepat Guna-LIPI, JI. KS. Tubun No. 5 Subang Jawa Barat 41213 \\ ${ }^{2}$ Politeknik Negeri Jember, Lingkungan Panji, Tegalgede, Kec. Sumbersari, Kabupaten Jember, \\ Jawa Timur 68124 \\ E-mail: enny.sh002@gmail.com
}

Diterima: 28 Februari 2020

Revisi: 4 Agustus 2020

Disetujui: 13 Agustus 2020

\begin{abstract}
ABSTRAK
Lemang merupakan makanan tradisional khas Indonesia terbuat dari campuran beras ketan dan santan. Tujuan penelitian ini mengetahui pengaruh proses pemasakan (kukus, rebus, dan bakar) dengan 3 variasi penggunaan pengawet (tanpa penambahan pengawet, potasium sorbat $250 \mathrm{ppm}$ dan asap cair 1 persen) terhadap perubahan karakteristik lemang selama masa penyimpanan. Parameter yang diamati selama penyimpanan pada suhu ruang adalah total bakteri (Total Plate Count) dan kapang/khamir; kadar air serta tekstur lemang (hardness, adhesiveness, cohesiveness, chewiness, dan springiness).Desain penelitian menggunakan Rancangan Acak Kelompok Lengkap (RAKL) yang disusun secara faktorial dengan 2 faktor yaitu (A) proses pemasakan dan (B) penggunaan pengawet. Hasil penelitian ini memperoleh bahwa metode pemasakan memengaruhi kadar air lemang. Lemang bakar memiliki kadar air terendah yaitu 37,2248 persen. Proses pemasakan dan penambahan asap cair memengaruhi tekstur lemang untuk parameter hardness. Lemang bakar memiliki nilai adhesiveness terendah. Akan tetapi, cohesiveness lemang tidak dipengaruhi oleh metode pemasakan dan penggunanan pengawet. Springiness lemang tertinggi dihasilkan oleh lemang kukus. Selama masa penyimpanan, lemang cenderung tidak mengalami perubahan kadar air dan tekstur. Metode pemasakan dan penggunaan pengawet tidak memengaruhi nilai TPC dan kapangkhamir lemang, dimana nilainya meningkat lemang selama masa penyimpanan.

kata kunci: Lemang, metode pemasakan, potasium sorbat, asap cair, masa penyimpanan
\end{abstract}

\section{ABSTRACT}

Lemang (rice bamboo) is a traditional Indonesian food prepared from a mix of glutinous rice and coconut milk. The purpose of this study was to investigate the effect of 3 cooking methods (steaming, boiling, and grilling) and the use of preservatives (without preservative, potassium sorbate of $250 \mathrm{ppm}$ and liquid smoke of 1 percent) on moisture content, the microbiological contents (Total Plate Count and moldyeast) and texture profiles (hardness, adhesiveness, cohesiveness, chewiness, and springiness) of lemang during storage. A Randomized Block Design (RBD) with two factors was employed to analyze the effects of treatments. Results showed that the cooking method influenced the moisture content of lemang. The grilled lemang exhibited the lowest moisture content of 37.22-48 percent. The cooking process and the addition of liquid smoke affect the texture of the lemang for hardness parameter. Besides, the grilled lemang exhibited a lower value of adhesiveness. The method of cooking and preservatives did not significantly affect the cohesiveness of lemang fruit. Lemang made by the steaming process indicated the highest springiness value The moisture content and texture properties of lemang did not alter during storage. The cooking methods and preservatives addition did not significantly influence the TPC and mold-yeast content of lemang in which their value increased during storage.

Keywords: Lemang (Rice Bamboo), cooking methods, potassium sorbate, liquid smoke, storage time

\section{PENDAHULUAN}

agam makanan tradisional dengan berbagai cita rasa yang khas lazim dijumpai dan dikonsumsi di Indonesia, termasuk lemang (Maflahah, 2012). Lemang adalah produk makanan tradisional yang khas dan unik karena proses pembuatannya menggunakan bambu 
yang dipanggang diatas tungku pembakaran (Sinaga, dkk., 2016; Wahyudi, dkk., 2017). Bahan utama lemang adalah ketan pulut dan santan.

Lemang memiliki karakteristik produk pangan semi basah (Intermediete Moisture Food) dengan kadar air antara 10-40 persen dan aktivitas air (aw) berkisar antara 0,65-0,90 sehingga merupakan media tumbuh untuk kapang-khamir (Soekarto, 1979). Pangan semi basah merupakan jenis makanan dengan campuran yang mengandung karbohidrat, lemak, protein dan komponen lain yang mengalami perubahan kimia. Peningkatan umur simpan produk semi basah berbasis ketan dan santan seperti dodol atau jenang telah dilakukan dengan penambahan bahan pengawet dan rekayasa proses (Kusumaningrum, dkk., 2017).

Penggunaan bahan pengawet dalam produk olahan pangan dapat mencegah dan menghambat kerusakan yang disebabkan oleh jamur, bakteri, dan mikroba pembusuk (Arini, 2017). Bahan pengawet yang food grade terdiri dari senyawa organik dan anorganik dalam bentuk asam atau garamnya dengan aktivitas dan efektifitas yang berbeda. Potasium sorbat merupakan garam kalium dari asam sorbat yang banyak digunakan produk makanan dan minuman, mudah larut dalam air, sehingga memudahkan dalam pencampurannya dengan larutan, stabil, dan dapat digunakan secara luas untuk pengawet berbagai produk pangan. Kalium sorbat memiliki 74 persen aktivitas antimikroba dengan cara memperpanjang fase adaptasi (lag phase) pertumbuhan mikroba (Stopforth, dkk., 2005).

Bahan pengawet non sintetis seperti asap cair juga dapat digunakan sebagai alternatif bahan pengawet yang lebih aman. dan dapat memperpanjang umur simpan (Lingbeck, dkk., 2014). Budijanto, dkk., (2008) melaporkan bahwa asap cair tempurung kelapa bersifat tidak toksik dan dapat digunakan untuk produk pangan, karena nilai LD50 lebih besar dari $15.000 \mathrm{mg} / \mathrm{kg}$ bobot badan mencit.

Penggunaan asap cair sebagai bahan pengawet biasanya pada pengawetan ikan, bakso, mie dan tahu. Asap cair mengandung campuran senyawa-senyawa aldehid, keton, furan, asam, ester, dan fenolik (Varlet, dkk., 2007). Kandungan senyawa-senyawa fenol dan asam mampu menghambat pertumbuhan jamur dan bakteri dengan (Alinti, dkk., 2017; Oramahi, dkk., 2011). Mekanisme penghambatan mikroba terjadi karena senyawa fenol, carbonil dan asamasam organik dapat menembus dinding sel menyebabkan denaturasi protein dan inaktivasi enzim pada membran dan dalam sitoplasma. dalam dinding sel. Selanjutnya membran sitoplasma rusak yang menyebabkan kerusakan DNA sehingga sel bakteri mati (Painter, 1998) Kholida (2018) telah menggunakan asap cair pada konsentrasi 3 persen untuk pengawet pangan semi basah berupa timbung (makanan khas Desa Pejangik yang cara pembuatannya mirip dengan lemang).

Proses pemasakan lemang dapat memengaruhi umur simpan produk karena metode pemasakan lemang berpengaruh pada aktivitas air atau aw produk. Prinsip dari pemasakan rebus dan kukus hampir sama yaitu melemahkan struktur dan pematangan jaringan yang menyebabkan makanan menjadi mudah diserap. Pemasakan kukus dan rebus media yang digunakan sebagai pemanas adalah air dan uap air. Sedangkan untuk bakar media yang digunakan yaitu panas dari api. Perbedaan metode pemasakan lemang diduga berpengaruh terhadap kharakteristik lemang dan umur simpannya.

Penelitian ini mempelajari pengaruh penggunakan bahan pengawet pada metode pemasakan lemang terhadap karakteristik produk lemang dan pengaruhnya selama masa penyimpanan.

\section{METODOLOGI}

\subsection{Proses Pembuatan Lemang}

Bahan utama pembuatan lemang adalah beras ketan, yang diperoleh dari petani di Kecamatan Binong, Kabupaten Subang-Jawa Barat. Bahan penunjang adalah santan kelapa, daun pisang dan buluh bambu yang diperoleh dari pasar lokal.

Proses pembuatan diawali dengan perendaman beras ketan selama satu jam dan ditiriskan. Tahap selanjutnya adalah memasukkan beras ketan dalam rongga 
bambu muda (panjang $20 \mathrm{~cm}$, diameter 5 $\mathrm{cm}$ ) yang didalamnya dilapisi daun pisang, lalu ditambahkan santan yang mengandung bahan pengawet sesuai formula dalam Tabel 1. Pengawet asap cair diperoleh dari bakaran batok kelapa.

Tabel 1. Formulasi Pembuatan Lemang

\begin{tabular}{lccc}
\hline \multicolumn{1}{c}{ Bahan } & B1 & B2 & B3 \\
\hline Ketan & $100 \mathrm{~g}$ & $100 \mathrm{~g}$ & $100 \mathrm{~g}$ \\
Santan & $80 \mathrm{ml}$ & $80 \mathrm{ml}$ & $80 \mathrm{ml}$ \\
kelapa & & & \\
Garam & $1,5 \%$ dari volume santan \\
Tanpa & - & - & - \\
pengawet & & & \\
Pengawet & - & $250 \mathrm{ppm}^{*}$ & - \\
PS-1000 & & & \\
Pemgawet & - & - & $1 \%{ }^{*}$ \\
Asap Cair & & & \\
Keterangan: *terhadap berat volume santan
\end{tabular}

Adapun pemasakan lemang dilakukan dengan tiga jenis proses yaitu kukus, rebus dan bakar masing-masing selama 2 jam. Masingmasing perlakuan menggunakan 6 lemang dalam bambu. Pengukusan dan perebusan dilakukan dalam wadah aluminium (tinggi 45 $\mathrm{cm}$ dan diameter $38 \mathrm{~cm}$ ) berkapasitas 15 liter air. Pembakaran menggunakan alat bakar lemang dengan spesifikasi kapasitas 10 bambu/batch, dan dimensi alat panjang $x$ lebar $x$ tinggi adalah $60 \times 40 \times 40 \mathrm{~cm}$ (Gambar 1).

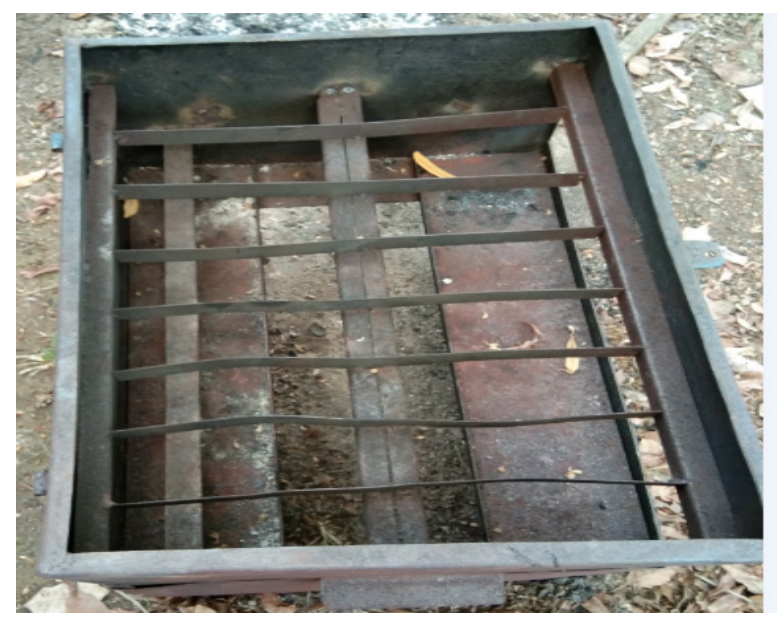

Gambar 1. Alat Bakar Lemang

Proses pembakaran dilakukan dengan cara meletakkan bambu diatas bara api dan memutar posisi bambu agar pemanasan merata. Suhu pemasakan yang digunakan yaitu pengukusan suhu uap panas yang terukur berkisar $80-95^{\circ} \mathrm{C}$, pada metode perebusan menggunakan suhu didih air $\left(100^{\circ} \mathrm{C}\right)$, dan pada metode pembakaran suhu panas yang terukur berkisar 128,4$211,6^{\circ} \mathrm{C}$ selama dua jam (Gambar 2).

\subsection{Pengujian Kadar air, Tekstur, TPC dan Kapang-khamir Lemang selama Masa Penyimpanan}

Produk lemang kukus, rebus dan panggang masih dalam bambu setelah pemasakan disimpan pada suhu ruang $\left(28-30^{\circ} \mathrm{C}\right)$. Setiap produk diuji kadar air, total bakteri, kapangkhamir dan profil teksturnya pada hari ke-0, 1 dan 2.

\subsection{Kadar air}

Penentuan kadar air menggunakan metode SNI 2891-1992: Cara Uji Makanan dan Minuman. Sampel sebanyak 1-2 g di letakkan pada cawan kaca yang telah diketahui bobotnya, lalu dipanakan dalam oven dengan suhu $105^{\circ} \mathrm{C}$ selama 3 jam. Selanjutnya diletakkan pada desikator selama 10-15 menit dan ditimbang. Proses pemanasan diulangi hingga diperoleh bobot konstan.

Kadar air $=\frac{(W 1-W 2)}{(W 1-W 0)} \times 100 \%$

Keterangan:

$\mathrm{W} 0=$ Berat cawan kosong $(\mathrm{g})$

$\mathrm{W} 1$ = Berat cawan dan sampel awal $(\mathrm{g})$

W2 = Berat kering cawan dan sampel setelah dikeringkan (g)

\subsection{Tekstur}

Tekstur lemang diukur menggunakan alat Texture analyser TA.XTPlus Stable Microsystem-UK (Lukman, dkk., 2009). Kondisi pengoperasian alat digunakan pre-test speed $2 \mathrm{~mm} / \mathrm{sec}$, test speed $1 \mathrm{~mm} / \mathrm{sec}$, post test speed $10 \mathrm{~mm} / \mathrm{sec}$, strain 30 persen, waktu 5 detik, trigger force $5 \mathrm{~g}$. Probe yang digunakan adalah P36R. Sampel lemang dipotong dengan ketebalan sekitar $6 \mathrm{~mm}$ lalu diukur untuk setiap sampel minimal 5 kali pengulangan. Data yang diperoleh adalah hardness, adhesiveness, cohesiveness, springiness, gumminess, chewiness dan resilience. Cohesiveness mengindikasikan kekuatan ikatan internal 


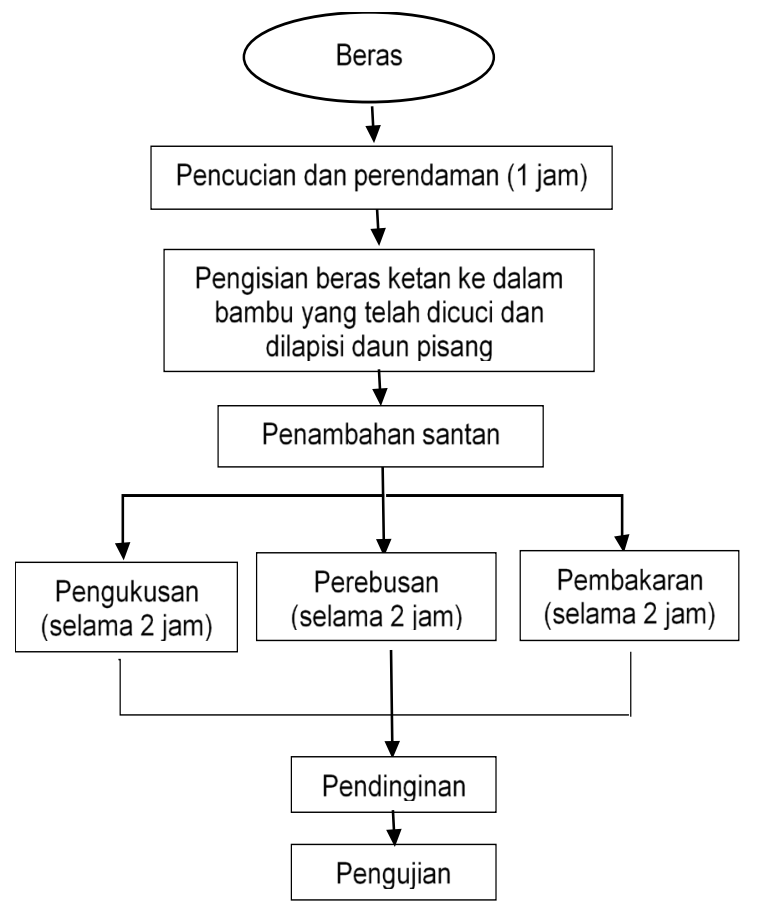

Gambar 2. Diagram Proses Pembuatan Lemang

yang membentuk matrik produk pangan. Nilai cohesiveness diperoleh dari rasio antara dua area kompresi sehingga tidak memiliki satuan. Cohesiveness dapat juga sebagai parameter tingkat kemudahan suatu bahan dihancurkan secara mekanis. Chewiness merupakan energi yang dibutuhkan untuk mengunyah makanan hingga makanan tersebut siap untuk ditelan.

\subsection{Total Bakteri (Total Plate Count) dan Kapang-khamir}

Pada pengujian masa simpan lemang dilakukan pengujian parameter mikrobiologi meliputi total bakteri atau uji TPC (Total Plate Count) dan kapang/khamir. Batas maksimal TPC dan kapang/khamir mengacu pada batas maksimal TPC dan kapang/khamir produk lontong, lemper ayam dan nasi bakar bersantan menurut Badan Pengawas Obat dan Makanan (BPOM) yaitu 1 x 105 kol/g (BPOM, 2013).

TPC atau Angka Lempeng Total (ALT) menunjukkan jumlah mikroba dalam suatu produk. Pengujian TPC secara umum tidak terkait secara langsung dengan bahaya keamanan pangan namun kadang bermanfaat untuk menunjukkan kualitas, masa simpan/waktu paruh, kontaminasi dan status higienis pada saat proses produksi. Total bakteri dan kapangkhamir pada lemang diukur menggunakan metode Total Plate Count atau angka lempeng total (BSN, 1992). Media yang digunakan adalah PCA (Plate Count Agar) sedangkan untuk pengenceran sampel digunakan BPW (Buffer Pepton Water).

Sampel diencerkan pada $10^{1}, 10^{2}, 10^{3}, 10^{4}$ dan $10^{5}$. Sterilisasi media menggunakan autoclave pada tekanan 15 psi selama 15 menit pada suhu $121^{\circ} \mathrm{C}$. Kemudian, sampel lemang secara aseptik ditimbang 10 gram lalu dimasukkan kedalam $90 \mathrm{ml}$ BPW steril sehingga diperoleh larutan dengan tingkat pengenceran $10^{1}$ dan dilanjutkan dengan pengenceran $10^{2}$, $10^{3}, 10^{4}$ dan $10^{5}$. Sampel dari setiap pengenceran dipipet $1 \mathrm{ml}$ untuk dipindahkan ke cawan petri steril.

Masing-masing cawan sampel ditambahkan media media PCA untuk TPC dan PDA untuk kapang/khamir sebanyak 15-20 ml. Tahap selanjutnya adalah inkubasi menggunakan inkubator selama 24 jam pada suhu $37^{\circ} \mathrm{C}$ untuk TPC. Inkubasi untuk analisa kapang-khamir pada suhu ruang dengan posisi terbalikselama 72 jam. Setelah masa inkubasi dilakukan penghitungan jumlah koloni pada setiap media. Perhitungan jumlah koloni mengikuti persamaan berikut:

Total bakteri $=$ jumlah koloni $x \mathrm{fp}$.

Kapang-khamir = jumlah koloni $x \mathrm{fp}$.

Keterangan:

$\mathrm{fp}=$ Faktor pengenceran

\subsection{Analisis statistik}

Desain penelitian menggunakan Rancangan Acak Kelompok Lengkap (RAKL) 2 faktor dengan 3 level dan 3 ulangan $(2 \times 3 \times 3)$. Faktor pertama adalah metode pemasakan $(A)$, terdiri dari 3 taraf, yaitu metode kukus $\left(A_{1}\right)$, metode rebus $\left(A_{2}\right)$, dan metode bakar $\left(A_{3}\right)$. Faktor kedua adalah penggunaan pengawet $(B)$, terdiri dari 3 taraf, yaitu: tanpa penambahan pengawet $\left(B_{1}\right)$, potasium sorbet pada konsentrasi $250 \mathrm{mg} / \mathrm{kg}$ $\left(B_{2}\right)$, dan asap cair pada konsentrasi 1 persen $\left(\mathrm{B}_{3}\right)$. Masing-masing lemang hasil perlakuan diamati perubahan karakteristiknya selama masa penyimpanan 3 hari.

Datayang diperoleh dianalisismenggunakan metode Analysis of Variance (ANOVA) pada taraf 5 persen dan uji lanjut menggunakan uji Duncan pada taraf 5 persen menggunakan MS Excel 97. 
Tabel 2. Kadar Air Lemang Berbagai Perlakuan dan Perubahannya selama Penyimpanan

\begin{tabular}{ccccc}
\hline \multirow{2}{*}{$\begin{array}{c}\text { Metode } \\
\text { Pemasakan }\end{array}$} & Waktu & \multicolumn{3}{c}{ Penggunaan Pengawet } \\
\cline { 2 - 5 } Penyimpanan & Tanpa pengawet & Potasium Sorbat & Asap Cair \\
\hline \multirow{2}{*}{ Kukus } & Hari ke-0 & $58,25 \pm 0,62^{\mathrm{bA}}$ & $54,93 \pm 2,42^{\mathrm{bA}}$ & $57,08 \pm 1,89^{\mathrm{bA}}$ \\
& Hari ke-1 & $54,21 \pm 4,93^{\mathrm{bA}}$ & $55,10 \pm 1,78^{\mathrm{bA}}$ & $55,37 \pm 1,87^{\mathrm{bA}}$ \\
& Hari ke-2 & $57,54 \pm 1,97^{\mathrm{bA}}$ & $54,80 \pm 4,42^{\mathrm{bA}}$ & $55,60 \pm 0,42^{\mathrm{bA}}$ \\
& Hari ke-0 & $58,10 \pm 2,10^{\mathrm{bA}}$ & $54,43 \pm 1,55^{\mathrm{bA}}$ & $53,19 \pm 2,95^{\mathrm{bA}}$ \\
\multirow{3}{*}{ Rebus } & Hari ke-1 & $58,76 \pm 1,27^{\mathrm{bA}}$ & $56,50 \pm 2,71^{\mathrm{bA}}$ & $57,20 \pm 5,10^{\mathrm{bA}}$ \\
& Hari ke-2 & $55,08 \pm 1,84^{\mathrm{bA}}$ & $55,66 \pm 2,17^{\mathrm{bA}}$ & $57,83 \pm 3,69^{\mathrm{bA}}$ \\
& Hari ke-0 & $46,80 \pm 6,45^{\mathrm{aA}}$ & $46,42 \pm 2,39^{\mathrm{aA}}$ & $41,53 \pm 0,95^{\mathrm{aA}}$ \\
& Hari ke-1 & $45,95 \pm 6,95^{\mathrm{aA}}$ & $46,62 \pm 4,41^{\mathrm{aA}}$ & $47,37 \pm 3,59^{\mathrm{aA}}$ \\
& Hari ke-2 & $47.15 \pm 4,91^{\mathrm{aA}}$ & $48,00 \pm 4,42^{\mathrm{aA}}$ & $37,22 \pm 1,45^{\mathrm{aA}}$ \\
\hline
\end{tabular}

Keterangan superscript:

1. Huruf kecil yang berbeda menunjukkan nilai yang berbeda nyata berdasarkan uji Duncan $($ Sig:0,05) untuk faktor metode pemasakan.

2. Huruf besar yang berbeda menunjukkan nilai yang berbeda nyata berdasarkan uji Duncan (Sig:0,05) untuk faktor penggunaan pengawet

\section{HASIL DAN PEMBAHASAN}

\subsection{Kadar Air Lemang}

Perlakuan pemasakan metode bakar berpengaruh signifikan terhadap kadar air lemang. Kadar air lemang bakar lebih rendah dibandingkan dengan lemang kukus dan rebus (Tabel 2). Pemasakan secara kukus dan rebus menggunakan air dan uap air sebagai media penghantar panas dan kontak dengan bahan, sehingga menyebabkan bertambahnya jumlah air yang terikat pada lemang (Sari dan Putri, 2018). Paramita dan Putri (2015) melaporkan bahwa proses pengukusan dapat meningkatkan kadar air flake talas karena adanya amilosa dan amilopektin yang bersifat mudah mengikat air, dimana amilopektin memiliki kapasitas pengikatan air yang lebih besar dan lebih lambat retrogradasinya. Beras ketan mengandung pati 71,36 persen; amilopektin 66,03 persen dan amilosa 5,33 persen (Refdi dan Fajri, 2017). Lemang bakar dimasak pada sistem terbuka menyebabkan uap air dari lemang lebih mudah terekspos keluar sistem atau ke lingkungan. Hal ini juga berkontribusi terhadap penurunan kadar air dalam lemang bakar karena tekanan uap air dalam bahan lebih tinggi dari lingkungan, sehingga terjadi perpindahan uap air dari lemang ke udara (Nilasari, dkk., 2017).

Adapun penggunaan pengawet tidak berpengaruh terhadap terhadap kadar air lemang (Tabel 2). Kedua jenis pengawet (potasium sorbat dan asap cair) bersifat larut dalam air, sehingga dapat masuk dan meresap dalam ketan selama proses pemasakan (EFSA, 2015).

Selama masa penyimpanan, kadar air lemang tidak mengalami perubahan. Menurut Ruksanan, dkk. (2020), produk pangan dengan kadar air tinggi akan menguapkan sebagian air ke lingkungan sampai terjadi kesetimbangan. Produk lemang yang masih dalam daun pisang dan bambu dapat menghambat proses penguapan air dari lemang ke lingkungan.

\subsection{Tekstur Lemang}

Metode pemasakan memengaruhi nilai hardness lemang. Lemang bakar lebih tinggi tingkat kekerasannya dibandingkan lemang kukus dan rebus (Tabel 3). Lemang bakar memiliki nilai hardness paling besar dibandingkan lemang kukus dan rebus. Pada proses pembakaran lemang, suhu sistem pemasakan lebih tinggi yaitu $128,4-211,6^{\circ} \mathrm{C}$ dibandingkan suhu kukus atau rebus yaitu $85-90^{\circ} \mathrm{C}$. Hal ini mengakibatkan air dalam lemang mudah menguap selama proses pembakaran. Penurunan kadar air lemang bakar memengaruhi proses gelatinisasi ketan selama pemasakan. Kadar air yang lebih rendah dalam lemang bakar menyebabkan molekul air yang terikat dalam rongga amilopektin lebih kecil sehingga teksturnya lebih keras (Luna, dkk., 2015). 
Tabel 3.Profil Tekstur Lemang Berbagai Perlakuan dan Perubahan Selama Penyimpanan

\begin{tabular}{|c|c|c|c|c|c|c|c|c|c|}
\hline \multirow{2}{*}{$\begin{array}{l}\text { Penggunaan } \\
\text { Pengawet }\end{array}$} & \multicolumn{3}{|c|}{ Metode Kukus } & \multicolumn{3}{|c|}{ Metode Rebus } & \multicolumn{3}{|c|}{ Metode Bakar } \\
\hline & $\begin{array}{l}\text { Hari } \\
\text { ke-0 }\end{array}$ & $\begin{array}{l}\text { Hari } \\
\text { ke-1 }\end{array}$ & $\begin{array}{l}\text { Hari } \\
\text { ke-2 }\end{array}$ & $\begin{array}{l}\text { Hari } \\
\text { ke-0 }\end{array}$ & $\begin{array}{l}\text { Hari } \\
\text { ke-1 }\end{array}$ & $\begin{array}{l}\text { Hari } \\
\text { ke-2 }\end{array}$ & $\begin{array}{l}\text { Hari } \\
\text { ke-0 }\end{array}$ & $\begin{array}{l}\text { Hari } \\
\text { ke-1 }\end{array}$ & $\begin{array}{l}\text { Hari } \\
\text { ke-2 }\end{array}$ \\
\hline \multicolumn{10}{|c|}{ Hardness (gf) } \\
\hline Tanpa Pengawet & $1400,3^{\mathrm{aA}}$ & $1907,8^{\mathrm{aA}}$ & $1375,5^{\mathrm{aA}}$ & $1389,0^{\mathrm{aA}}$ & $1305,8^{\mathrm{aA}}$ & $2030,0^{\mathrm{aA}}$ & $1376,6^{\mathrm{bA}}$ & $2263,7^{\mathrm{bA}}$ & $3273,8^{\mathrm{bA}}$ \\
\hline Potasium Sorbat & $1488,1^{\mathrm{aAB}}$ & $1091,4^{\mathrm{aAB}}$ & $1403,9^{\mathrm{aAB}}$ & $1302,1^{\mathrm{aAB}}$ & $1977,5^{\mathrm{aB}}$ & $2021,9^{\mathrm{aAB}}$ & $4816,5^{\mathrm{bAB}}$ & $2683,4^{\mathrm{bAB}}$ & $2813,1^{\mathrm{bAB}}$ \\
\hline Asap Cair & $1304,9^{\mathrm{aB}}$ & $1251,7^{\mathrm{aB}}$ & $1939,1^{\mathrm{aB}}$ & $2620,6^{\mathrm{aB}}$ & $1607,1^{\mathrm{aB}}$ & $1289,2^{\mathrm{aB}}$ & $1926,7^{\mathrm{bB}}$ & $4773,1^{\text {bB }}$ & $10043,7^{\mathrm{bB}}$ \\
\hline \multicolumn{10}{|c|}{ Adhesiveness(gs) } \\
\hline Tanpa Pengawet & $-821,8^{\mathrm{aA}}$ & $-1018,6^{a}$ & $-265,5^{\mathrm{aA}}$ & $-758,3^{\mathrm{aA}}$ & $-810,1^{\mathrm{aA}}$ & $-418,9^{a A}$ & $-385,0^{\mathrm{bA}}$ & $-543,3^{\mathrm{bA}}$ & $-87,3^{\mathrm{bA}}$ \\
\hline Potasium Sorbat & $-708,3^{\mathrm{aA}}$ & $-604,3^{\mathrm{aA}}$ & $-506,1^{\mathrm{aA}}$ & $-620,8^{\mathrm{aA}}$ & $-1005,0^{\mathrm{aA}}$ & $-507,1^{\mathrm{aA}}$ & $-352,3^{\mathrm{bA}}$ & $-277,1^{\mathrm{bA}}$ & $-211,4^{\mathrm{bA}}$ \\
\hline Asap Cair & $-833^{\mathrm{aA}}$ & $-737,8^{\mathrm{dA}}$ & $-760,5^{\mathrm{aA}}$ & $-1127,0^{\mathrm{aA}}$ & $-532,5^{\mathrm{aA}}$ & $-211,2^{\mathrm{aA}}$ & $-483,8^{\mathrm{bA}}$ & $-106,7^{\mathrm{bA}}$ & $-9,4^{\mathrm{bA}}$ \\
\hline \multicolumn{10}{|c|}{ Springiness } \\
\hline Tanpa Pengawet & $0,86^{\mathrm{bAB}}$ & $0,85^{\mathrm{bAB}}$ & $0,77^{\mathrm{bAB}}$ & $0,83^{\mathrm{aAB}}$ & $0,83^{\mathrm{aAB}}$ & $0,72^{\mathrm{aAB}}$ & $0,83^{\mathrm{aAB}}$ & $0,81^{\mathrm{AB}}$ & $0,79^{\mathrm{aAB}}$ \\
\hline Potasium Sorbat & $0,86^{\mathrm{bB}}$ & $0,85^{\mathrm{bB}}$ & $0,81^{\mathrm{Bb}}$ & $0,87^{\mathrm{aB}}$ & $0,82^{\mathrm{aB}}$ & $0,83^{\mathrm{aB}}$ & $0,78^{\mathrm{aB}}$ & $0,80^{\mathrm{aB}}$ & $0,73^{\mathrm{aB}}$ \\
\hline Asap Cair & $0,83^{\mathrm{bA}}$ & $0,84^{\mathrm{bA}}$ & $0,79^{\mathrm{bA}}$ & $0,81^{\mathrm{aA}}$ & $0,73^{\mathrm{aA}}$ & $0,73^{\mathrm{aA}}$ & $0,80^{\mathrm{aA}}$ & $0,77^{\mathrm{aA}}$ & $0,72^{\mathrm{aA}}$ \\
\hline \multicolumn{10}{|c|}{ Chewiness } \\
\hline Tanpa Pengawet & $740,8^{\mathrm{aA}}$ & $978,8^{\mathrm{aA}}$ & $593,8^{\mathrm{aA}}$ & $696,7^{\mathrm{aA}}$ & $702,1^{\mathrm{aA}}$ & $812,2^{\mathrm{aA}}$ & $767,0^{\mathrm{bA}}$ & $1296,9^{\mathrm{bA}}$ & $1550,2^{\mathrm{bA}}$ \\
\hline Potasium Sorbat & $786,3^{\mathrm{aAB}}$ & $596,8^{\mathrm{aAB}}$ & $674,4^{\mathrm{aAB}}$ & $759,4^{\mathrm{aAB}}$ & $1001,7^{\mathrm{aAB}}$ & $1011,8^{\mathrm{aAB}}$ & $1612,1^{\mathrm{bAB}}$ & $1445,3^{\mathrm{bAB}}$ & $1143,2^{\mathrm{bAB}}$ \\
\hline Asap Cair & $670,1^{\mathrm{aB}}$ & $684,0^{\mathrm{aB}}$ & $1018,9^{a B}$ & $1189,4^{\mathrm{aB}}$ & $709,3^{\mathrm{aB}}$ & $516,8^{\mathrm{aB}}$ & $1076,0^{\mathrm{bB}}$ & $2356,5^{\mathrm{bB}}$ & $4005,11^{\mathrm{bB}}$ \\
\hline \multicolumn{10}{|c|}{ Cohesiveness } \\
\hline Tanpa Pengawet & $0,62^{\mathrm{aA}}$ & $0,59^{\mathrm{aA}}$ & $0,57^{\mathrm{aA}}$ & $0,62^{\mathrm{aA}}$ & $0,65^{\mathrm{aA}}$ & $0,56^{\mathrm{aA}}$ & $0,66^{\mathrm{aA}}$ & $0,70^{\mathrm{aA}}$ & $0,60^{\mathrm{aA}}$ \\
\hline Potasium Sorbat & $0,62^{\mathrm{aA}}$ & $0,63^{\mathrm{aA}}$ & $0,50^{\mathrm{aA}}$ & $0,67^{\mathrm{aA}}$ & $0,62^{\mathrm{aA}}$ & $0,61^{\mathrm{aA}}$ & $0,55^{\mathrm{aA}}$ & $0,67^{\mathrm{aA}}$ & $0,55^{\mathrm{aA}}$ \\
\hline Asap Cair & $0,62^{\mathrm{aA}}$ & $0,64^{\mathrm{aA}}$ & $0,65^{\mathrm{aA}}$ & $0,57^{\mathrm{aA}}$ & $0,61^{\mathrm{aA}}$ & $0,57^{\mathrm{aA}}$ & $0,65^{\mathrm{aA}}$ & $0,64^{\mathrm{aA}}$ & $0,54^{\mathrm{aA}}$ \\
\hline
\end{tabular}

Keterangan superscript:

1.Huruf kecil yang berbeda menunjukkan nilai yang berbeda nyata berdasarkan uji Duncan (Sig:0,05) untuk faktor metode pemasakan.

2.Huruf besar yang berbeda menunjukkan nilai yang berbeda nyata berdasarkan uji Duncan (Sig:0,05) untuk faktor penggunaan pengawet.

Penggunaan pengawet asap cair meningkatkan hardness lemang dibanding lemang yang tanpa penggunaan pengawet. Ketan mengandung amilopektin tinggi, sehingga memiliki struktur granula yang lebih kompak, ruang udara antar granula dan ukuran granula lebih besar (Luna, dkk., 2015). Hal ini membutuhkan lebih banyak air untuk proses gelatinisasi. Penggunaan asap cair yang mengandung senyawa-senyawa fenolik dan karbonil air meresap dan terikat ke dalam beras ketan selama proses gelatinisasi, sehingga menghambat masuknya molekul air dalam tekan (Yusnaini, dkk., 2012). Hal ini dapat menyebabkan proses gelatinisasi ketan berkurang, sehingga tekstur lemang menjadi lebih keras.

Penggunaan potasium sorbat tidak berbeda nyata terhadap tingkat kekerasan lemang. Potasium sorbat yang ditambahkan dalam santan dapat berfungsi sebagai emulsifier, namun sistem emulsi santan rusak akibat pemanasan selama 2 jam proses pemasakan (Wulandari, dkk., 2017). Potasium sorbat akan terlarut dalam fase air dan masuk ke dalam ketan. Interaksi ikatan hidrogen dapat terjadi antara potasium sorbat dan pati membentuk jejaring dalam matrik dan berpengaruh terhadap teksturnya pada penambahan $\leq 5$ persen (Shen, dkk., 2010). Dalam penelitian ini digunakan potasium sorbat $250 \mathrm{ppm}$ atau 0,025 persen belum memberikan pengaruh signifikan. Selama masa penyimpanan, hardness lemang cenderung tidak berubah kecuali lemang bakar dengan penggunaan asap cair cenderung mengalami peningkatan.

Adhesiveness menunjukkan tingkat kelengketan produk merupakan gaya yang dimiliki oleh bahan untuk menempel pada bahan lain. Nilai adhesiveness lemang dipengaruhi oleh metode pemasakan. Metode kukus 
dan rebus memiliki nilai adhesiveness lebih besar yang artinya lebih lengket dibandingkan metode bakar. Beras ketan memiliki kandungan amilopektin tinggi yaitu 88-89 persen (Suriani, 2015). Pada metode kukus dan rebus uap air yang masuk ke dalam rongga amilopektin lebih banyak menyebabkan pati berubah menjadi gel lebih banyak. Hal ini yang menyebabkan tekstur menjadi lebih lengket. Lemang bakar memiliki nilai adhesiveness paling rendah untuk ketiga jenis bahan pengawet jika dibandingkan dengan lemang kukus dan rebus. Hal ini dapat disebabkan oleh penurunan kadar air pada permukaan lemang serta case hardening akibat proses retrogradasi yang terjadi selama proses penyimpanan dan menyebabkan permukaan lemang menjadi lebih kering (Rahmadi, dkk., 2019).

Adapun penambahan bahan pengawet tidak berpengaruh signifikan terhadap adhesiveness. Tidak ada interaksi antara penggunaan pengawet dan metode pemasakan lemang. Selama masa penyimpanan adhesiveness lemang cenderung menurun. Proses retrogradasi dapat menyebabkan permukaan lemang menjadi lebih tidak lengket.

Nilai cohesiveness lemang yang dihasilkan berkisar antara 0,54-0,70 (Tabel 3). Nilai cohesiveness tidak dipengaruhi oleh metode pemasakan dan penggunaan pengawet. Cohesiveness lemang dipengaruhi komponen pati dari ketan dan santan. Pati mengalami gelatinisasidengan adanya air darisantan selama proses pemasakan. Energi panas pada saat pemasakan lemang menyebabkan terputusnya ikatan hidrogen dalam pati, sehingga air yang terkandung dalam santan masuk ke dalam granula pati dan membentuk ikatan hidrogen dengan molekul penyusun pati (amilosa dan amilo pektin). Granula mengembang kemudian pecah yang menyebabkan perubahan viskositas menjadi lebih kental, hal ini yang disebut gelatinisasi (Kusumaningrum, dkk., 2017). Gelatinisasi membentuk tekstur lemang yang kompak. Sedangkan santan mengandung 54 persen air, 35 persen lemak, dan 11 persen padatan non lemak. Emulsi santan rusak akibat proses pemasakan, sehingga air meresap ke dalam ketan dan lemak serta protein berada di permukaan lemang (Kailaku, dkk., 2012).
Selama masa penyimpanan, cohesiveness lemang tidak mengalami perubahan.

Springiness digunakan untuk menentukan seberapa produk dapat kembali ke kondisi awal setelah diberi tekanan pertama kali (Szczesniak, 2002). Springiness menunjukkan tingkat elastisitas produk, dimana jika nilainya semakin mendekati 1 maka semakin tinggi tingkat elastisitas produk. Nilai springiness produk lemang berkisar antara 0,72-0,86 (Tabel 3). Analisis sidik ragam menunjukkan bahwa nilai springiness lemang dipengaruhi oleh metode pemasakan dan penambahan pengawet. Lemang kukus memiliki nilai springiness tertinggi. Springiness lemang dibentuk oleh rongga dalam dalam matrik lemang hasil proses gelatinisasi ketan dengan amilopektin tinggi. Menurut Collado, dkk. (2001), gelatinisasi dipengaruhi oleh jumlah air dan panas. Proses transfer panas oleh uap air selama proses pengukusan terjadi pada semua bagian lemang secara merata, sehingga adonan akan saling terikat dan membentuk matriks lemang yang kohesif dan elastis. Sedangkan pada lemang rebus, bagian bawah bambu tercelup dalam air dan tertutup oleh dasar panci perebusan. Gelatinisasi lemang bakar hanya dipengaruhi oleh air yang terkandung dalam santan dan sebagian menguap ke lingkungan.

Penggunaan asap cair menurunkan springiness lemang. Hal ini dapat disebabkan molekul-molekul komponen asap cair dimungkinkan berinteraksi dengan komponen pati dalam ketan, sehingga mengurangi interaksi pati dengan air. Selama masa penyimpanan, springiness lemang cenderung tidak mengalami perubahan.

Nilai chewiness lemang berkisar antara 516,8-4005,1 (Tabel 3). Metode pemasakan dan jenis pengawet berpengaruh signifikan terhadap chewiness lemang dan ada interaksi antara kedua faktor. Pemasakan bakar memiliki nilai chewiness yang lebih tinggi dibandingkan kukus dan rebus. Chewiness berhubungan dengan tingkat kekerasan produk, semakin tinggi nilai chewiness maka semakin keras produk tersebut (Caine, dkk., 2003). Chewiness merupakan kekenyalan yang dimiliki produk bertekstur padat. Lemang bakar dengan penggunaan asap cair memikili nilai chewiness tertinggi. Asap cair 
Tabel 4. Nilai TPC dan Kapang-Khamir Lemang

\begin{tabular}{|c|c|c|c|c|}
\hline $\begin{array}{l}\text { Penambahan } \\
\text { Pengawet }\end{array}$ & $\begin{array}{c}\text { Metode } \\
\text { Pemasakan }\end{array}$ & $\begin{array}{c}\text { Waktu } \\
\text { Penyimpanan }\end{array}$ & $\begin{array}{c}\text { Total Mikroba } \\
\text { (Cfu/gram) }\end{array}$ & $\begin{array}{c}\text { Total Kapang/khamir } \\
\text { (Cfu/gram) }\end{array}$ \\
\hline \multirow{9}{*}{$\begin{array}{c}\text { Tanpa } \\
\text { pengawet }\end{array}$} & \multirow[t]{3}{*}{ Kukus } & Hari ke-0 & $3.33 \times 10^{0 \mathrm{aA}}$ & $1.67 \times 10^{0 \mathrm{aA}}$ \\
\hline & & Hari ke-1 & $9.80 \times 10^{4 a A}$ & $1.11 \times 10^{5 \mathrm{aA}}$ \\
\hline & & Hari ke-2 & $4.51 \times 10^{5 \mathrm{aA}}$ & $2.91 \times 10^{5 \mathrm{aA}}$ \\
\hline & \multirow[t]{3}{*}{ Rebus } & Hari ke-0 & $0^{\mathrm{aA}}$ & $1.33 \times 10^{1 \mathrm{aA}}$ \\
\hline & & Hari ke-1 & $1.73 \times 10^{5 \mathrm{aA}}$ & $1.94 \times 10^{5 \mathrm{aA}}$ \\
\hline & & Hari ke-2 & $9.34 \times 10^{7 \mathrm{aA}}$ & $5.56 \times 10^{7 \mathrm{aA}}$ \\
\hline & \multirow[t]{3}{*}{ Bakar } & Hari ke-0 & $1.67 \times 10^{0 \mathrm{aA}}$ & $3.33 \times 10^{0 \mathrm{aA}}$ \\
\hline & & Hari ke-1 & $3.66 \times 10^{6 \mathrm{aA}}$ & $6.16 \times 10^{6 \mathrm{aA}}$ \\
\hline & & Hari ke-2 & $6.51 \times 10^{7 \mathrm{aA}}$ & $5.59 \times 10^{7 \mathrm{aA}}$ \\
\hline \multirow[t]{9}{*}{ Potasium Sorbat } & \multirow[t]{3}{*}{ Kukus } & Hari ke-0 & $3.33 \times 10^{0 \mathrm{aA}}$ & $1.67 \times 10^{0 \mathrm{aA}}$ \\
\hline & & Hari ke-1 & $2.02 \times 10^{4 a A}$ & $4.23 \times 10^{4 \mathrm{aA}}$ \\
\hline & & Hari ke-2 & $4.34 \times 10^{5 \mathrm{aA}}$ & $2.53 \times 10^{5 \mathrm{aA}}$ \\
\hline & \multirow[t]{3}{*}{ Rebus } & Hari ke-0 & $1.67 \times 10^{0 \mathrm{aA}}$ & $1.33 \times 10^{1 \mathrm{aA}}$ \\
\hline & & Hari ke-1 & $2.51 \times 10^{5 \mathrm{aA}}$ & $7.93 \times 10^{4 \mathrm{aA}}$ \\
\hline & & Hari ke-2 & $3.06 \times 10^{7 \mathrm{aA}}$ & $2.46 \times 10^{7 \mathrm{aA}}$ \\
\hline & \multirow[t]{3}{*}{ Bakar } & Hari ke-0 & $2.05 \times 10^{3 \mathrm{aA}}$ & $1.74 \times 10^{3 \mathrm{aA}}$ \\
\hline & & Hari ke-1 & $5.84 \times 10^{5 \mathrm{aA}}$ & $3.10 \times 10^{5 \mathrm{aA}}$ \\
\hline & & Hari ke-2 & $8.40 \times 10^{7 \mathrm{aA}}$ & $4.90 \times 10^{7 \mathrm{aA}}$ \\
\hline \multirow[t]{9}{*}{ Asap cair } & \multirow[t]{3}{*}{ Kukus } & Hari ke-0 & $0^{\mathrm{aA}}$ & $8.33 \times 10^{0 \mathrm{aA}}$ \\
\hline & & Hari ke-1 & $1.43 \times 10^{5 \mathrm{aA}}$ & $9.38 \times 10^{4 a A}$ \\
\hline & & Hari ke-2 & $4.40 \times 10^{5 \mathrm{aA}}$ & $1.51 \times 10^{5 \mathrm{aA}}$ \\
\hline & \multirow[t]{3}{*}{ Rebus } & Hari ke-0 & $1.67 \times 10^{0 \mathrm{aA}}$ & $3.33 \times 10^{0 \mathrm{aA}}$ \\
\hline & & Hari ke-1 & $1.63 \times 10^{7 \mathrm{aA}}$ & $9.68 \times 10^{6 \mathrm{aA}}$ \\
\hline & & Hari ke-2 & $6.84 \times 10^{7 \mathrm{aA}}$ & $6.36 \times 10^{7 \mathrm{aA}}$ \\
\hline & \multirow[t]{3}{*}{ Bakar } & Hari ke-0 & $1.67 \times 10^{0 \mathrm{aA}}$ & $3.33 \times 10^{0 \mathrm{aA}}$ \\
\hline & & Hari ke-1 & $1.63 \times 10^{7 \mathrm{aA}}$ & $8.71 \times 10^{6 \mathrm{aA}}$ \\
\hline & & Hari ke-2 & $6.75 \times 10^{7 \mathrm{aA}}$ & $2.71 \times 10^{7 \mathrm{aA}}$ \\
\hline
\end{tabular}

Keterangan superscript:

1. Huruf kecil yang berbeda menunjukkan nilai yang berbeda nyata berdasarkan uji Duncan $(S i g: 0,05)$ untuk faktor metode pemasakan.

2. Huruf besar yang berbeda menunjukkan nilai yang berbeda nyata berdasarkan uji Duncan $($ Sig:0,05) untuk faktor penggunaan pengawet.

mengandung senyawa-senyawa fenolik dan karbonil yang meresap ke dalam beras ketan selama proses gelatinisasi dan terikat sehingga menghambat masuknya molekul air (Yusnaini, dkk., 2012). Hal ini menyebabkan tekstur lemang tidak elastis. Hasil ini sejalan dengan penurunan kadar air dalam lemang oleh penambahan asap cair.

Selama penyimpanan nilai chewiness mengalami perubahan dan cenderung meningkat. Hal ini yang dapat dipengaruhi oleh proses retrogradasi komponen pati dalam matrik lemang sehingga lebih keras dan kenyal.

\subsection{Uji Mikrobiologi (TPC dan Kapang/Khamir)}

Cemaran mikrobiologi merupakan parameter keamanan pangan yang menjadi syarat mutu kelayakan produk untuk dikonsumsi serta indikasi higienitas dan sanitasi produk serta proses produksi. Batas maksimal TPC dan kapang/khamir mengacu pada batas maksimal TPC dan kapang/khamir produk lontong, lemper ayam dan nasi bakar bersantan menurut Badan Pengawas Obat dan Makanan yaitu $1 \times 10^{5} \mathrm{kol} / \mathrm{g}$ (BPOM, 2012). 
Jenis metode pemasakan lemang dan penggunaan pengawet tidak berpengaruh nyata terhadap nilai TPC maupun kapang-khamir lemang (Tabel 4). Lemang termasuk produk pangan semi basah dengan kadar air lebih dari 40 persen dan aktivitas air (aw) berkisar antara 0,65-0,90 yang merupakan media tumbuh untuk kapang-khamir (Soekarto, 1979). Selain itu santan mengandung protein dan lemak yang sangat cocok bagi pertumbuhan mikroba (Kailaku, dkk., 2012). Penggunaan potasium sorbat $250 \mathrm{ppm}$ dan asap cair 1 persen belum dapat menghambat pertumbuhan mikroba pada lemang selama masa penyimpanan. Batas penggunaan potasium sorbat sebagai bahan tambahan pangan maksimal 1000mg/ $\mathrm{kg}$ (BPOM, 2013). Menurut Food and Agriculture Organization (FAO, 2019) asam sorbat atau potassium sorbat dijinkan untuk digunakan dalam produk pangan pada level kurang dari 0,3 persen atau 3000ppm. Kholida (2018) melaporkan bahwa penggunaan asap cair sebanyak 4 persen dapat menurunkan kandungan TPC makanan timbung selama masa penyimpanan, namun dapat diterima berdasarkan uji organoleptik pada penambahan 3 persen.

\section{KESIMPULAN}

Metode pemasakan berpengaruh terhadap kadar air dan tekstur lemang. Metode bakar menghasilkan lemang dengan kadar air paling rendah, hardness dan chewiness paling tinggi, serta adhesiveness lebih rendah, sedangkan lemang kukus memiliki nilai springiness tertinggi. Penggunaan pengawet tidak berpengaruh signifikan terhadap kadar air dan tekstur lemang. Selama masa penyimpanan cenderung tidak terjadi perubahan kadar air dan tekstur lemang. Metode pemasakan dan penggunaan pengawet tidak berpengaruh terhadap nilai TPC dan kapang-khamir lemang. Nilai TPC dan kapang-khamir lemang meningkat selama masa penyimpanan.

\section{UCAPAN TERIMA KASIH}

Ucapan terima kasih kami sampaikan kepada Dinas Pemberdayaan Masyarakat Kelurahan Kota Tebing Tinggi serta tim penelitian dan pengkajian lemang kota Tebing Tinggi dan sivitas P2TTGLIPI yang turut membantu pelaksanaan kegiatan penelitian ini.

\section{DAFTAR PUSTAKA}

Alinti, Z., S. M. Timbowo, dan F. Mentang. 2017. Kadar Air, pH, dan Kapang Ikan Cakalang (Katsuwonus Pelamis L.) Asap Cair Yang Dikemas Vakum dan Non Vakum pada Penyimpanan Dingin. Media Teknologi Hasil Perikanan, 6(1), 6. https://doi. org/10.35800/mthp.6.1.2018.16851

Arini, L. D. D. (2017). Faktor-faktor Penyebab dan Karakteristik Makanan Kadaluarsa yang Berdampak Buruk pada kesehatan Masyarakat. Jurnal Teknologi Dan Industri Pangan, 2(1): 15-24.

BPOM, 2013. Peraturan Kepala BPOM Republik Indonesia Nomor 36 Tahun 2013 Tentang Batas Maksimum Penggunaan Bahan Tambahan Pangan Pengawet. Jakarta.

BPOM, 2012. Pedoman Kriteria Cemaran pada Pangan Siap Saji dan Pangan Industri Rumah Tangga. Jakarta.

BSN, 1992.SNI Nomor 01-2891-1992:Cara Uji Makanan dan Minuman. Jakarta.

Budijanto, S., R. Hasbullah, S. Prabawati, S. Setyadjit, and I. Zuraida. 2008. Identification and safety test on liquid smoke made from coconut shell for food product. Indonesian Journal of Agricultural Postharvest Research, 5(1): 32-40.

Caine, W. R., J. L. Aalhus, D. R. Best, M.E.R. Dugan, $M$ and L.E. Jeremiah. 2003. Relationship of texture profile analysis and Warner-Bratzler shear force with sensory characteristics of beef rib steaks. Meat Science, 64: 333-339.

Collado, L. S., L. B. Mabesa, C.G. Oates, and H. Corke. 2001. Bihon-type noodles from heatmoisture-treated sweet potato starch. Journal of Food Science, 66(4), 604-609. https://doi. org/10.1111/j.1365-2621.2001.tb04608.x

EFSA. 2015. Scientific Opinion on the re-evaluation of sorbic acid (E 200), potassium sorbate (E 202) and calcium sorbate (E 203) as food additives. EFSA Journal, 13(6), 1-91. https://doi. org/10.2903/j.efsa.2015.4144.

FAO. 2019. Codex Standard 192/1995 General Standard for Food Additives, Revision 2019. http://www.fao.org/fao-who-codexalimentarius/en/

Kailaku, S. I., T. Hidayat, and D. A. Setiabudy. 2012. Effects of Homogenization Conditions on Physical Characteristics and Quality of Coconut Milk during Storage. Jurnal Littri, 18(1):31-39.

Kholida, S. N. 2018. Pengaruh Penambahan Asap Cair Terhadap Daya Simpan Jajanan Tradisional Timbung. Universitas Mataram.

Kusumaningrum, A., D. Ariani, dan Y. Khasanah, 2017. Pengaruh Waktu Penyimpanan Terhadap Karakteristik Makanan Tradisional "Jenang Saban." Jurnal Penelitian Teknologi Industri, 9(1): 23-36. 
Lingbeck, J. M., P. Cordero, C.A. O’Bryan, M.G. Johnson, S.C. Ricke, and P.G. Crandall. 2014. Functionality of liquid smoke as an all-natural antimicrobial in food preservation. Meat Science, 97(2), 197-206. https://doi.org/10.1016/j. meatsci.2014.02.003

Lukman, I., N. Huda, and N. Ismail. 2009. Physicochemical and sensory properties of commercial chicken nuggets. Asian Journal of Food and Agro-Industry, 2(02): 171-180.

Luna, P., H. Herawati, S. Widowati, dan A.B. Prianto. 2015. Pengaruh Kandungan Amilosa terhadap Karakteristik Fisik dan Organoleptik Nasi Instan. Jurnal Penelitian Pascapanen Pertanian, 12(1): $1-10$.

Maflahah, I. 2012. Desain Kemasan Makanan Tradisional Madura dalam Rangka Pengembangan IKM. AGROINTEK, 6(2): 118-122.

Nasional, D. S. 1992. SNI 01-2891-1992: Cara Uji Makanan dan Minuman. Jakarta: Badan Standarisasi Nasional.

Nilasari, O. W., W. H Susanto, J.M. Maligan. 2017. Pengaruh Suhu dan Lama Pemasakan terhadap Karakteristik Lempok Labu Kuning (Waluh). Jurnal Pangan dan Agroindustri, 5(3): 15-26.

Oramahi, H., F. Diba, dan Wahdina. 2011. Aktivitas Antijamur Asap Cair dari Serbuk Gergaji Kayu Akasia (Acacia mangium Willd) dan Kayu Laban (Vitex pubescens Vahl). Bionatura - Jurnal IImuIImu Hayati Dan Fisik, 13(1): 79-84.

Painter, T. J. 1998. Carbohydrate polymers in food preservation: An integrated view of the Maillard reaction with special reference to discoveries of preserved foods in Sphagnum-dominated peat bogs. Carbohydrate Polymers, 36(4), 335-347. https://doi.org/10.1016/S0144-8617(97)00258-0

Paramita, A. H., dan W. D. R. Putri. 2015. Pengaruh Penambahan Tepung Bengkuang dan Lama Pengukusan terhadap Karakteristik Fisik, Kimia dan Organoleptik Flake Talas. Jurnal Pangan Dan Agroindustri, 3(3): 1071-1082.

Rahmadi, I., Sugiyono, \& N.E. Suyatna. 2019. Teknologi Pengolahan Ketupat: Perubahan Karakteristik Fisikokimia dan Mikrobiologi selama Pengolahan dan Penyimpanan. Jurnal Pangan, 28(2): 161-170. 10.33964/jp.v28i2.437.

Refdi, C. W. dan P. Y. Fajri. 2017. Komposisi Gizi dan Pati Tepung Beras Rendang dari beberapa Sentra produksi di Kota Payakumbuh Sumatera Barat. Jurnal Teknologi Pertanian Andalas, 21(1): 40-44.

Ruksanan, Rustanari, S. Nggolele, dan Dahniar. 2020. Pengaruh Lama Penyimpanan pada Suhu Kamar terhadap Kualitas Ikan Cepa Asin Kering. Sultra Journal of Agricultural Research, 1(1): 25-35.
Sari, N. P., dan W.D.R. Putri. 2018. Pengaruh Lama Penyimpanan Dan Metode Pemasakan Terhadap Karakteristik Fisikokimia Labu Kuning (Cucurbita moschata). Jurnal Pangan dan Agroindustri, 6(1): 17-27. https://doi. org/10.21776/ub.jpa.2018.006.01.3

Shen, X. L., J. M. Wu, Y. Chen, and G. Zhao. 2010. Antimicrobial and physical properties of sweet potato starch films incorporated with potassium sorbate or chitosan. Food Hydrocolloids, 24(4): 285-290. https://doi.org/10.1016/j. foodhyd.2009.10.003

Sinaga, N., S.B.Daulay dan L.A. Harahap. 2016. Uji Suhu terhadap Kualitas Lemang pada Alat Pemasak Lemang Listrik Tipe Vertikal (Efect of Temperature on The Quality of Lemang Using Vertical Type Lemang Cooking Appliance ). Jurnal Rekayasa Pangan Dan Pertanian, 4(3): 433-439.

Stopforth, J. D., J.N. Sofos, and F.F Busta. 2005. Sorbic Acid and Sorbates. In P. M. Davidson, J. N. Sofos, \& A. L. Branen (Eds.), Antiicrobials in Food (Third Edit: 49-90). Boca Raton: Taylor \& Francis.

Suriani, S. 2015. Analisis Proksimat Pada Beras Ketan Varietas Putih ((Oryza sativa glutinosa). Al-Kimia, 3(1): 81-91. https://doi.org/10.24252/ AL-KIMIA.V3I1.1663

Szczesniak, A. S. 2002. Texture is a sensory property. Food Quality and Preference, 13:215-225.

Varlet, V., C. Prost, and T. Serot. 2007. Volatile aldehydes in smoked fish: Analysis methods, occurence and mechanisms of formation. Food Chemistry, 105(4): 1536-1556. https://doi. org/10.1016/j.foodchem.2007.03.041

Wahyudi, B. A., F. A. Octavia, M. Hadipraja, S. Isnaeniah, and V. Viriani. 2017. Lemang ( Rice bamboo ) as a representative of typical Malay food in Indonesia. Journal of Ethnic Foods, 4(1): 3-7. https://doi.org/10.1016/j.jef.2017.02.006

Wulandari, N., I. Lestari, dan N. Alfiani, N. 2017. Peningkatan Umur Simpan Produk Santan Kelapa dengan Aplikasi Bahan Tambahan Pangan dan Teknik Pasteurisasi. Jurnal Mutu Pangan, 4(1): 30-37.

Yusnaini, Soeparno, E. Suryanto, dan R. Armunanto. 2012. Physical, chemical and sensory properties of kenari (Canariun indicum L.) shell liquid smoke-immersed-beef on different level of dilution. Journal of the Indonesian Tropical Animal Agriculture, 37(1):27-33. https://doi. org/10.14710/jitaa.37.1.27-33 


\section{BIODATA PENULIS:}

Enny Sholichah dilahirkan di Tuban, 16 September 1980. Penulis menyelesaikan pendidikan S1 Kimia Universitas Brawijaya lulus pada tahun 2002. Melanjutkan Pascasarjana S2 Kimia di Universitas Gadjah Mada Yogyakarta lulus tahun 2017.

Rima Kumalasari dilahirkan di Surakarta, 23 Oktober 1980. Penulis menyelesaikan S1 Teknologi Pangan dan Hasil Pertanian Universitas Lampung tahun 2002 dan S2 Magister Manajemen Institut Pertanian Bogor lulus pada tahun 2006.

Nok Afifah dilahirkan di Pemalang, 30 Mei 1978. Penulis menyelesaikan pendidikan S1 Teknik Kimia Universitas Gadjah Mada tahun 2001 dan S2 Teknik Kimia Universitas Indonesia lulus pada tahun 2014.

Novita Indrianti dilahirkan di Sleman, 23 November 1987. Penulis menyelesaikan pendidikan S1 Teknologi Pangan dan Hasil Pertanian Universitas Gadjah Mada lulus pada tahun 2009 dan S2 IImu dan Teknologi Pangan Universitas Gadjah Mada lulus pada tahun 2017.

Faradila Nurintan Firdaus dilahirkan di Jombang, 27 Mei 1998. Saat ini sedang menempuh pendidikan D3 Teknologi Industri Pangan Politeknik Negeri Jember.

Ari Rahayuningtyas dilahirkan di Kediri, 11 Januari 1981. Penulis menyelesaikan pendidikan S1 Teknik Elektro Universitas Gadjah Mada lulus pada tahun 2005 dan S2 Teknik Elektro Institut Teknologi Bandung lulus pada tahun 2019.

Titik Budiati dilahirkan di Yogyakarta, 20 Mei 1970. Penulis menyelesaikan pendidikan S1 Teknologi Hasil Pertanian Universitas Brawijaya lulus pada tahun 1994, S2 Food Safety Wageningen University lulus pada tahun 2007 dan S3 Food Safety University Sains Malaysia lulus pada tahun 2014. 
Halaman ini sengaja dikosongkan 